\title{
Article
}

\section{New Heroines for New Causes: How provincial women promoted a revisionist history through post-suffrage pageants}

\author{
Binns, Amy
}

Available at http://clok.uclan.ac.uk/17322/

Binns, Amy ORCID: 0000-0002-9173-3108 (2017) New Heroines for New Causes: How provincial women promoted a revisionist history through postsuffrage pageants. Women's History Review, 27 (2). pp. 221-246. ISSN 09612025

It is advisable to refer to the publisher's version if you intend to cite from the work. http://dx.doi.org/10.1080/09612025.2017.1313806

For more information about UCLan's research in this area go to http://www.uclan.ac.uk/researchgroups/ and search for <name of research Group>.

For information about Research generally at UCLan please go to http://www.uclan.ac.uk/research/

All outputs in CLoK are protected by Intellectual Property Rights law, including Copyright law. Copyright, IPR and Moral Rights for the works on this site are retained by the individual authors and/or other copyright owners. Terms and conditions for use of this material are defined in the policies page.

\section{CLoK}

Central Lancashire online Knowledge www.clok.uclan.ac.uk

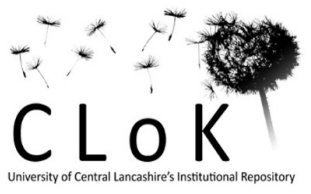


New Heroines for New Causes:

How provincial women promoted a revisionist history through post-suffrage pageants

Author: Amy Binns 


\begin{abstract}
The selection and promotion of powerful role models was a major source of inspiration during the suffrage movement, with figures such as Joan of Arc invoked as justifying women's rights. This research shows the tradition continued post-1914, but with a different focus. Well over a hundred amateur pageants of noble women were staged with a changing pantheon reflecting women's new roles and aspirations.
\end{abstract}

These events were staged by both religious and secular groups throughout Britain, but were most common in the small industrial towns of the Pennines, the South West and North East where Nonconformity was strong. The pageants varied from a couple of dozen performers to a thousand, with newspapers frequently praising their elaborate costumes and

historical accuracy. Though certain formats and characters appeared regularly, narrative choices often reflected the organisers' tastes, sometimes introducing local heroines or reclaiming the Bible as a source of inspiration for powerful women.

Bio: Author Amy Binns is a senior lecturer in the journalism department of the University of Central Lancashire. Her publications include journal articles: Don't Feed the Trolls! Managing troublemakers in magazines' online communities, Journalism Practice 6 (4), 547-562; Twitter city and Facebook village: Teenage girls' personas and experiences influenced by choice architecture in social networking sites, Journal of Media Practice 15 (2), 71-91; Fair game? Journalists' experiences of online abuse, The Journal of Applied Journalism and Media Studies, in press, 2017; and a book published by Grace Judson Press, 2013, Valley of a Hundred Chapels: Yorkshire non-conformists' lives and legacies. Correspondence to: Amy Binns, Greenbank Building, University of Central Lancashire, Preston, PR1 2HE. Tel: 07810 295219. Email: abinns@uclan.ac.uk

\title{
Introduction
}


On August 2, 1932, Grace Cockcroft ripped the used pages out of her shorthand exercise book ${ }^{1}$ and began planning her 'Pageant of Noble Women', to be staged by her friends at the Birchcliffe Baptist Chapel in the Yorkshire mill town of Hebden Bridge. Her choices could be described as a revisionist women's history, which ignored the figures celebrated in school textbooks, public statues and stained glass windows in favour of a different pantheon. Grace included the Greek mathematician Hypatia, martyred nurse Edith Cavell, suffragist Frances Willard, and then still active socialist Helen Keller, as well as a reframing of the Bible in a group including the sexually liberated Woman of Samaria, warrior prophetess Deborah and successful trader Lydia.

And Grace and her friends were not the only women to do so. Their pageant, simultaneously modest and dizzyingly ambitious, was part of a nationwide enthusiasm by women's groups to reframe history, and create a new, post-suffrage pantheon of feminist heroines. Like many grassroots movements, it appears to have spread through some organised bodies, but also sprung up spontaneously in unconnected areas. In fact, searches of local newspaper archives ${ }^{2}$, though digitisation is far from complete, contain references to more than 100 different 'famous women' pageants between 1915 and 1953, peaking in the 1930s, suggesting the practice was widespread.

This paper aims to provide evidence, not just of the fact of the pageants, but also that they were consciously aimed at providing inspiration and a new historical narrative for the rising generation, with introductions that directly appealed to the audience to challenge the dearth of women in their history books. How successful they were in establishing these women as a new pantheon long-term is debatable, as will be seen through this paper. This research will further demonstrate that, even away from the large urban centres, women were using whatever networks they had to actively educate themselves and others to take a wider role in society, using suffragists' techniques for a new purpose. 
Unlike Cicely Hamilton's famous 'Pageant of Great Women'ㄱ, this was largely a working-class and provincial movement, with a particularly non-conformist flavour through the Baptist and various Methodist churches. Though certain characters appear over and over, there were also personal choices including local heroines, or eye-catchingly feminist Biblical groups. But although we can recognise the creation of these pageants as a feminist action and the characters as feminist heroines, the choices owe more to the constitutional suffrage movement than the radical suffragettes. Although appearing in many Liberal and Labour strongholds, they may be termed "small-c conservative", sometimes with a nationalist or patriotic tenor which is at odds with established left-leaning feminist thought and traditions.

\section{Forerunners: use of pageantry by suffragists, traditionalists and others}

The dozens of provincial "noble women" events described in this research did not spring from nowhere, but grew out of a culture of processions and pageants both religious and secular, feminist and mainstream.

The most obvious parallels are with the suffrage series of public spectacles, including marches, demonstrations and processions, staged by both constitutional and militant wings of the women's suffrage movement between 1906 and 1914; these were probably inspired by Sherborne's famous 1905 pageant which sparked the craze of "pageanitis" that spread all over Britain and the $\mathrm{US}^{4}$, creating narratives around towns, cities, themes and even races well into the $1930 \mathrm{~s}^{5}$. Any production involving dozens of amateur actors in homemade costumes appearing as the giants of history has comic potential, exploited in E.L. Benson's "Mapp and Lucia", and Virginia Woolf's "Between the Acts", but the organisers' intent of creating and promoting an authorised version of their town's history was serious. 
Lisa Tickner ${ }^{6}$ notes that the suffrage marches gained impact because they were the first time middle class women had appeared on the streets in force. This may be so, but these parades followed much earlier Northern traditions of Whit Walks, Sunday School Anniversary parades and Band of Hope processions, often led by respectable church and chapel-going women. The first Band of Hope procession in Leeds in 1850 with banners and brass bands, publicised the Temperance cause and they were hugely popular into the $20^{\text {th }}$ Century. $^{7}$

The suffrage events which followed them were a form of propaganda partly aimed at the new mass-read daily newspapers such as the Mirror, but were also covered by more establishment titles. ${ }^{8}$ Possibly the first major public attempt at a feminist revisionist history through choice of celebrities or role models was the suffrage march of June 1908 through London, which featured tributes to notable women living and dead. The anti-suffragette Times ${ }^{9}$ clearly wanted to point out that the parade was propaganda when their rather snide report of the event stated:

the organization and stage-management were admirable, and would have reflected credit on the most experienced political agent. Nothing was left to chance or improvisation: and no circumstance that ingenuity or imagination could contrive was lacking to make the show imposing to the eye.

Colour and beauty were consciously used to soften the abruptness of the suffragists' message and appease critics who accused them of lack of femininity. The first on 13 June was notable for its banners, displayed in advance of the parade and which even the Times described as "worthy to rank as one of the art exhibitions of the year" ${ }^{10}$ whilst making the backhanded compliment that women's entry into politics would at least improve the aesthetics of agitation.

However, the banners, largely the designs of professional artist Mary Lowndes, were in themselves an expression of a femininity that their critics denied them, and were important 
propaganda in their own right. As The Daily Chronicle wrote 'the beauty of the needlework.. should convince the most sceptical that it is possible for a woman to use a needle even when she is also wanting a vote'. ${ }^{11}$

These banners were made for organisations including nurses, artists, gymnasts, gardeners and graduates, and several commemorated individuals including Joan of Arc, singer Jenny Lind, Marie Curie, Elizabeth Fry, traveller Mary Kingsley, Grace Darling, the first British doctor Elizabeth Blackwell, artists Mary Moser and Angelica Kauffman and 'Victoria, Queen and Mother'. The procession passed the gentlemen's clubs. The Observer said:

By special permission of Queen Victoria, the magic word "Crimea" was charged on Miss Nightingale's arms - just as if she had been a regiment. Nurses in uniform carried this honourable banner. The veterans of the Service Club bared their heads with reverential homage as this noble memorial came in view; and the crowd, quick to catch an emotion, ceased from their joking and bared their heads as well. ${ }^{12}$

The parades were a retort to the cartoonists who portrayed suffragists as harridans and old maids. The event was also photographed by Britain's first female press photographer Christina Broom for a lucrative series of postcards. ${ }^{13}$

The idea of a a pantheon of heroic and learned women justifying the right to the vote was formalised in Cicely Hamilton's Pageant of Great Women ${ }^{14}$ which debuted in London in 1909 and toured Britain for three years. In each town, local women would take the 50 roles, who were introduced as part of a debate between "Woman" and "Sir Prejudice", presided over by "Justice". Staging within a theatre meant some problems of marches (poor weather, logistics, unruly crowds) were solved, and they also permitted an added dimension.. Although most of the characters did not speak (which made it easier for non-professionals to stage), a formal argument could be presented, culminating in Sir Prejudice being bundled off stage by the group of warrior women. The groupings also allowed a projection of female solidarity 
across time and national boundaries, although Cameron points out that this shows signs of strain as women who would have been at odds (such as Boadicea fighting for the British and Joan of Arc fighting against them) were presented together ${ }^{15}$. The groups were photographed for postcards, and the script sold as a book. Suffrage plays and tableaux were also staged privately by amateur groups for fundraising. ${ }^{16}$

The concept also continued to be popular on marches, with a Great Women section of the suffragettes' Coronation Parade in 1911. One woman dressed as Joan of Arc on horseback, symbolising the heroism and militant martyrdom central to the WSPU. The parade was intended to rival the official parade the following week and was the last and greatest of its kind in Britain. Tickner wrote: "With it they reached the limit of public spectacle, not just as a political device but as a practical possibility."17

The pragmatic use of beauty and spectacle to answer criticisms of lack of feminity was adopted by the US suffragist movement, whose parades in 1911, 1912 and 1913 were led by "the most beautiful suffragette", Inez Milholland, once appearing as Joan of Arc. ${ }^{18}$

Harriot Stanton Blatch, president of the Women's Political Union, shows the consciousness of the organisers when she wrote in the New York Tribune before the 1912 parade:

Look at our daily press, note the space it is giving to the May 4 demonstration, and surely the question is answered why we have a parade. A parade, then, is of news value... But, more than this, - we who are behind the scenes know the effect of a procession on our own marching ranks. We know that is a source of inspiration for our workers, and that, above all, it cultivates in them courage and determination. We parade mainly because if feeds the enthusiasm of our army. ${ }^{19}$

This double use of the spectacle both as propaganda for the cause and for the women themselves is revealing. Even the word "inspiration" is one that is repeatedly used by magazine editors today in women's power lists. ${ }^{20}$ 


\section{Changing Times: the post-militant era}

Although women did not gain the vote until 1918, the era of active militant campaigning ended with the outbreak of war in 1914, and the war years could be seen as ushering in a new, patriotic expression of feminism, in which agitation against the state was replaced by active work with and for the state. This was typified by Emmeline and Christabel Pankhurst's renaming of their periodical The Suffragette, as Britannia, and lobbying the Government to allow women to join industry while men went to the front. ${ }^{21}$ It is against this background that the first of these pageants took place simultaneously in Lancashire and Bristol in 1915.

The post-war, post-suffrage years that followed have been seen as suffering a backlash of conservatism, as played out in women's magazines, but there is a growing view that feminism did not die away, but found new expression as women negotiated a new citizenship. Its various forms were explored in the Women's History Review special edition $1: 3^{22}$. Evidence was also reviewed by Adrian Bingham, who concluded "the interwar period cannot simply be regarded as an era of domesticity and retreat."23

The sponsoring organisations of these pageants were largely Christian, complementing Jacqueline deVries' work on denominational feminism in the CofE and RC churches ${ }^{24}$, in which she argued that the category of religion has been neglected in the examination of interwar feminism, and that, in religious contexts, the British women's movement made considerable progress in this period.

And although the period has been seen as one of "conservative backlash", Alison Light pointed out it is hard to reconcile this with the "buoyant sense of excitement and release" in new opportunities, from tennis clubs and cinema going to accessible mortgages. 
For Light, much women's culture cannot be made sense of "unless we admit that feminist work must deal with the conservative as well as the radical imagination.... On the whole feminists have preferred to believe that feminism and conservatism are mutually exclusive." 25

This confident and optimistic claiming and expression of a new citizenship will be seen to be reflected in the pageants described below. This research reflects the more confident expression of feminism in religious contexts described by deVries, and widens our understanding of how working-class and non-conformist women in particular saw their new roles. Their choice of heroines and role models holds up a mirror to their beliefs as they adjusted to their new positions as citizens.

\section{Methodology}

Using the online British Newspaper Archives held by the British Library, all references to amateur pageants were traced using the search terms "Masque of Noble Women", "Pageant of Noble Women", "Pageant of Great Women" and "Pageant of Famous Women". These references range from paid adverts and short editorial notices of future events to reviews with photographs and full details of characters and players. The results are inevitably incomplete, as many amateur events will not have been reported at the time, particularly as these were often only a single performance. Not all the British Library's archive has been digitised, so many entire newspapers are missing, or are only represented for certain years. For example, none of Glasgow's eleven newspapers have been digitised for later than 1900, which means Glasgow is almost entirely unrepresented in these results. However, the Gloucester Citizen, Gloucester Journal and Gloucestershire Echo have all been digitised to 1950, making it over-represented. In addition, the Optical Character Recognition software is estimated to be between $81-99 \%$ accurate for scanning historical newspapers on a 
per character basis. A search for an exact phrase may miss a result because it misreads one or more characters, resulting in much lower accuracy levels ${ }^{26}$. The phrase "pageant of noble women", at 19 characters, may have an accuracy rate of at best $81 \%$, and possibly much lower, ie, many references are inevitably being missed. Further Google searches were used for the above phrases to find other pageants, but this resulted in only a handful of extra events.

In total, the result is a list of 117 separate pageants or tableaux, of which thirty two have character lists. As explained above, this is inevitably a very partial picture and the true numbers are likely to be much higher. Further 'Pageants of Noble Women' were also found in the 1930s in Australia, New Zealand and Zaire, but full searches of these archives were not conducted.

The results were plotted on Excel including details (as far as available) of the organising groups, title of reporting newspaper and date of cutting (not performance), place of performance and characters. This allowed for ranking of popularity of characters, plotting of dates, and searches on types of churches and other groups. Mapping was only tentatively attempted due to the many information black holes caused by missing newspapers, but some conclusions can be made, especially when combined with the organisations producing the events. The full spreadsheets are available to other researchers, see supplemental data below.

Further to this, archives of the Temperance movement White Ribbon magazine revealed discussion of the earliest masques organised from 1915 onwards, which were so popular a box of costumes was bought and hired out to Y-branches (for young women). From the writer's comments in 1916, and the fact that a Y Branch in Dundee performed it in 1926, it seems possible that this version alone was produced hundreds of times. 
The large number of performances and the fact that some lists of characters are identical or near-identical suggests that at least some versions must have been published. However, this appears not to be the case. Searches of the British Library records and other online manuscript databases produced no results. The White Ribbon magazine states their "Masque of Noble Women" script was not published, a typed copy was lent to branches to make their own copies, and the original returned; this has apparently been lost. I have only sourced one entire typewritten script, from a box of manuscripts and programmes. The Australian author, Lucy Stevens, wrote and produced more than a dozen plays now held by Queensland university. I have also found two pages of a script in the Bristol record office, kept along with the programme produced by the Ladies' Dorcas Society, 1933. Some newspaper reports quote speeches or describe scenes, further details are given in results below.

The fact that the many versions and performances of this production have left so little trace is perhaps a reflection on the very low value assigned to women's historical narratives at the time, and particularly working class women's narratives and culture. This is illustrated by the fact that a similar play is available in several American university libraries, and digitised as part of the Hathi Trust. Women of Cornell University produced "Urania: A Pageant of Noble Ladies" (my italics) in 1917, and this script was published, but it is significantly different in content and tone. Women of ancient times, including Sappho of Lesbia and Semiramis of Babylon, represent the various Cornell colleges. They converse with Urania, and the college Masters appear with their insignia and address $\operatorname{her}^{27}$.

It seems likely that this has survived partly because it was produced by an institution which routinely archived materials from student performances, whilst many of the British productions were not produced by well-organised institutions with procedures and archive facilities. However, some were, and yet these scripts have still been lost. The Methodist 
churches have archives of their own with further extensive collections in external organisations such as Manchester's John Rylands library. There are many documents relating to the Girls' Friendly Society in the British Library. These institutions could have also archived materials from their women's productions, but they did not.

The contrast between the status and respect given to the students' manuscript, and the many chapel and girls' club versions, could hardly be more stark. While the noble ladies have been assured archival and now digital immortality, the noble women's scripts appear to have been circulated in a manner almost reminiscient of samizdat literature, and are now all but lost. Presumably they were passed around until too dog-eared to be of use then discarded. It is hopeful that, as digitisation continues, one may appear in a box of programmes, but at present it seems impossible to trace a complete British manuscript.

\section{Pageants For a New Cause: findings}

\section{The Pageants: framing and structure}

Newspapers referred to these events as pageants, masques and tableaux, the terms apparently being used almost interchangeably. Traditionally, a masque was performed by masked performers representing allegorical characters and included song and pantomime. There is no indication that these women wore masks, but perhaps the term seemed appropriate as women were representing such famous national figures. Pageants were originally outdoor performances usually incorporating a procession, but although processions do not seem to have happened in these performances, the term was adopted as the chronological order often used suggested a march through history. Tableaux, in contrast, implied a series of scenes by costumed actors who may represent their parts in silence. This 
seems closer to the actual performances we know of, but all three terms were commonly used.

The first amateur production I have found reference to was in 1915 , when G\&H Wakeford wrote a "Masque of Noble Women" staged by Bristol Girl Guides. Grace Wakeford (Mrs Copeman) was "at the piano”, while a Kathleen Copeman (Grace's daughter?) played Queen Victoria. It seems likely the Wakefords were aware of the "Pageant of Great Women" as they use a similar style of groupings with a central character introducing them. However, where Hamilton used a debate between Woman and Prejudice, the Wakefords' play was clearly what we would now understand as a revisionist history aimed at the rising generation.

Twenty years later, another performance of the same masque is reported by the Western Gazette ${ }^{28}$ which explains in more detail:
In the masque, 'The Child of the Present', Beryl Gray falls asleep after reading a book of history with the sense that good things have been performed by men, but few by women. Then Clio, the Muse of heroic poetry (Miss Durbin), appears and introduces the 'Champions of Liberty',...'The Light Bringers',...'Women of Great Renown', ....'Life Savers'....'Seers of Vision'....'Uplifting and Purity',... and a 'Mother'.

One local newspaper report indicates the format of the Bristol production, and possibly the entire script, was passed to the British Women's Temperance Association and rewritten by a Bradford minister Arthur Kinsey for an initial performance in London in 1917, using identical choices of characters ${ }^{29}$. Rather confusingly, the White Ribbon magazines of the British Temperance Association describe a very similar "Masque of Noble Women" performed by Lancashire girls of a Y-Branch (for young women) in 1915, ie at almost the same time as the Bristol production. Like many grassroots movements, it seems possible that 
two or more people had similar ideas at the same time. The White Ribbon report met with so much enthusiasm that a box of costumes was bought for hire.

In February 1916, White Ribbon magazine states: “As an attraction to the outsiders, a means of making money for any and every cause, and as an education to most people, this Masque in unsurpassed." Later that year, another article states, apparently in response to numerous inquiries, that the costumes will be sent in time for the dress rehearsal, but their popularity is shown in the comments:

...it must be pointed out that these rehearsals must be held near the date of the performance. A week or ten days beforehand is practically impossible, as rarely in the season are the costumes unbooked for so long... Only too often when the boxes have been returned have the costumes been found to have been altered. Skirts have been shortened (indeed, one would imagine that trains were unheard of things, so often has E B Browning's dress been shortened at the back).... When the boxes go, as so often they do, from Branch to Branch, it is almost impossible to trace those things which are missing when they return to their headquarters at last.

Over the years, the concept was copied by many other organisations, often church or youth groups. Of thirty two newspaper reports which include full cast lists, I have found nineteen pageants or masques which mention Clio and seventeen with a "child of the present" or "dreamer". Some of these have different characters, suggesting that the format was used but the heroines chosen could be varied. However, this core concept could be altered to add different emphases.

An interesting variation was given by the Dorcas Society at Trinity Presbyterian Church, Bristol, in $1933 .{ }^{30}$ Although all roles in the tableaux were taken by women (including the male roles opposite the heroines, such as Sir Walter Raleigh opposite Elizabeth 1), the narrator and child parts were taken by a real-life father and son, the father explaining to his son the many examples of heroism shown by women. This shows the organisers 
understood boys also needed this social education, and that this had to come not from preaching women but from adult men they could respect.

The Girls' Friendly Society had a different aim - they were unusual in that a condition of membership was having always borne a "good character", usually interpreted as virginity. Run by middle-class CofE ladies, it was aimed at working girls, particularly servants, who were in danger of being corrupted as they left their own family circles ${ }^{31}$. In 1925, Chelmsford GFS incorporated these institutional ideals and structures into a similar framing device, with a warning not to rely on young men. The Chelmsford Chronicle reported $^{32}$

The prologue was based upon a scene at a London railway station, showing the arrival of a country girl, whose young man acquaintance had not fulfilled his promise to meet her. Frightened and friendless, the girl was on the point of despair, when a GFS lady met her, and, offering help and comfort, took her to a restaurant. There the unhappy girl spoke of her desolation, but words of encouragement were given by the lady friend, who reminded her of the famous women of Essex who had made history in the past.

This theme of providing a new, more inspiring history for a new era continued right through to the war years. In 1940, in a performance by the Ladies' Committee of Methodist Centenary Hall, Penzance ${ }^{33}$, the spirit of the Twentieth Century claimed women had achieved little compared to men, but spirits of History, Biography and Literature refuted this, leaving

Twentieth Century to reply in closing:

Ye spirits of the past, I give you thanks,

That ye have taught me larger lessons far

And shown me as a bright and guiding star

The noble part that women of all ranks

Have nobly played in perfecting God's plan.

Man's comrades now, not slaves, we forward go

That, banded in one purpose, hearts aglow,

The realm of darkness and of hate shall fall

And Christ's great Kingdom be the goal of all. 
The line 'Man's comrades now, not slaves, we forward go', indicated the concept that women had entered a new era, and required, through pageants such as this one, a guiding star for their new journey.

\section{The Pageants: Organisers}

The explicit aim of providing younger people with a new, more inspiring history, partly explains why these pageants were so popular with youth groups. Of 117 reported shows, twenty one were by youth organisations such as girls' schools, Girl Guides, Girls' Friendly Societies and the Y (youth) branch of the British Women's Temperance Association.

They are also markedly by Christian organisations and particularly non-conformists: seven had links to Baptist Churches, fifty one to Methodists and three to other nonconformist churches. The Temperance movement, though in theory non-denominational, was in practice most common amongst non-conformists, particularly Methodists.

Table 1: Pageant organising bodies mentioned in the British Newspaper Archive.

\begin{tabular}{|l|r|}
\hline Organisers & \\
\hline Methodist churches, sisterhoods etc. & 51 \\
\hline Baptist churches, sewing circles, Temperance groups etc & 4 \\
\hline Temperance women's groups & 4 \\
\hline Temperance Y-branches (youth) & 5 \\
\hline Other non-conformists, Congregationalists etc & 8 \\
\hline Other non-conformist youth & 2 \\
\hline Mothers' Unions (CofE) & 4 \\
\hline Schools & 11 \\
\hline Secular youth groups including guides & \\
\hline
\end{tabular}




\begin{tabular}{|l|r|}
\hline Women's Institutes & 6 \\
\hline Other secular groups & 17 \\
\hline & $\mathbf{2 1}$ \\
\hline Total youth groups both secular and Christian & $\mathbf{7 9}$ \\
\hline groups & $\mathbf{3 7}$ \\
\hline Total secular including secular youth groups & \\
\hline
\end{tabular}

Notes: This does not include events mentioned in the White Ribbon magazine. Two events have so little information they cannot be categorised. Two Temperance events were held in Baptist venues, but these have been categorised as Temperance events to avoid double counting. Although the Guides movement was at the time a Christian movement which included a promise to God in the vows, this has been classed as a secular movement as groups were not specifically organised by the Church of England and could commonly meet in schools and be named for towns not churches.

In contrast, this research only uncovered four pageants by Mothers' Union branches, which are linked to CofE churches ${ }^{34}$. Five were Women's Institutes and three by their urban sister institutions, the Townswomen's Guilds. One of these, in Sunderland, had more than a thousand performers ${ }^{35}$. The remaining secular organisations are very varied, including Girls' Friendly Societies, VAD detachments, a business and professional women's club, amateur dramatic groups etc. It is worth noting that I could not find a single event organised by the most patriarchal of organisations, the Roman Catholic church.

As stated, it is not possible to reliably map these events due to the incomplete archive, but there appears to be a crossover with non-conformist stronghold areas as mapped by Hugh McLeod $^{36}$ : the South West, a strip up the Pennines and the coastal towns of the North East

Figure 1: National map of pageants mentioned in the British Newspaper Archive. 


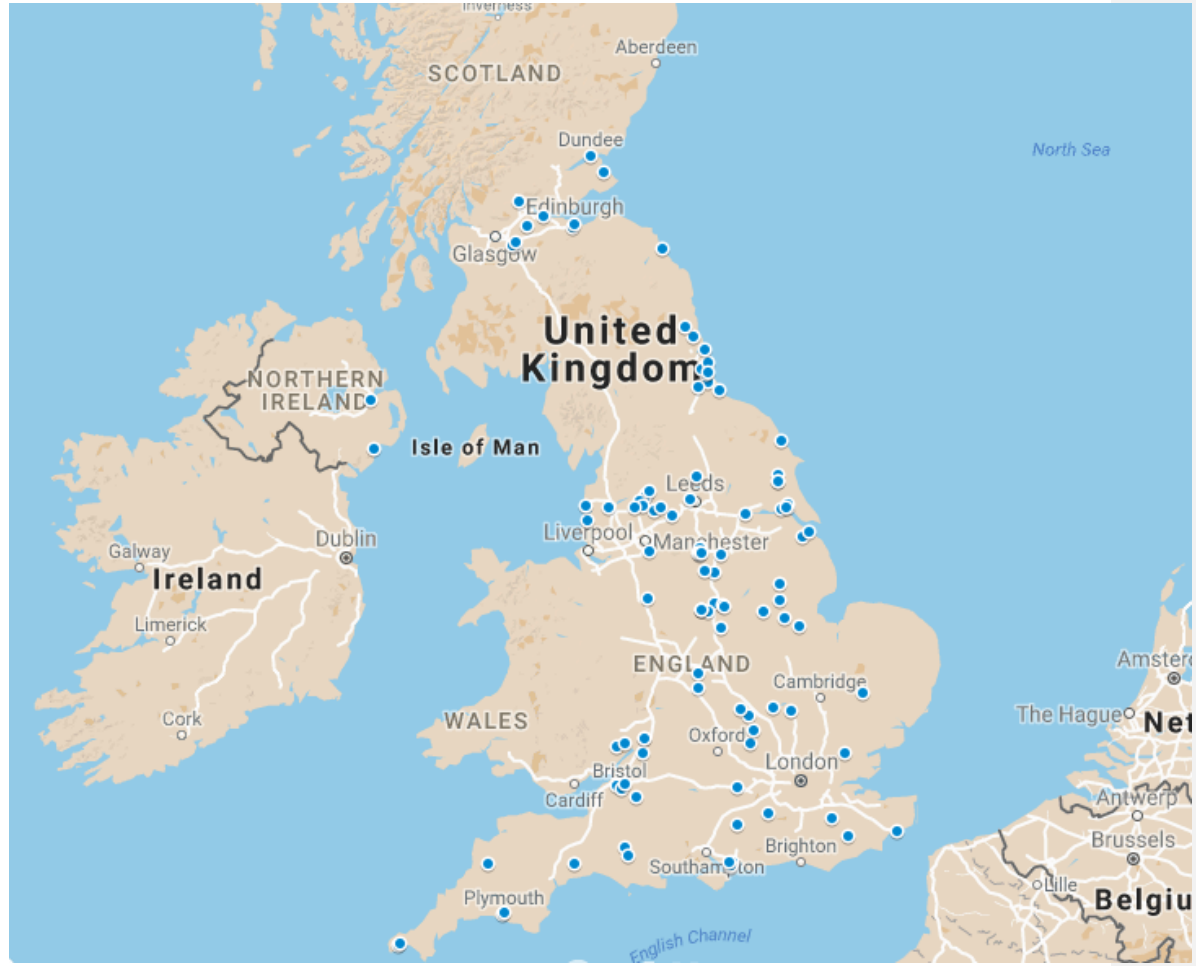

The national map above shows the spread of these events across the British Isles, from Dundee to Penzance and across into Northern Ireland. In the South East, the major establishment cities of London, Oxford and Cambridge have no events. This may be because no such pageants were held there, but it may be because the local papers were less parochial and chapels were less likely to advertise or be given space in them. Wales shows as empty, given its strong non-conformist culture I think it likely that this is due to incomplete digitisation of the newspapers for this region. The regional map for the North below makes clear how the events skirt the thriving cities of Manchester, Liverpool and Leeds, though again the local papers may have had less space for this type of event. There are also no events in the ancient, cathedral towns of Lancaster, York and Chester. Instead they are clustered in 
the small towns of East Lancashire, the Methodist stronghold of Sheffield, and scattered up the coast.

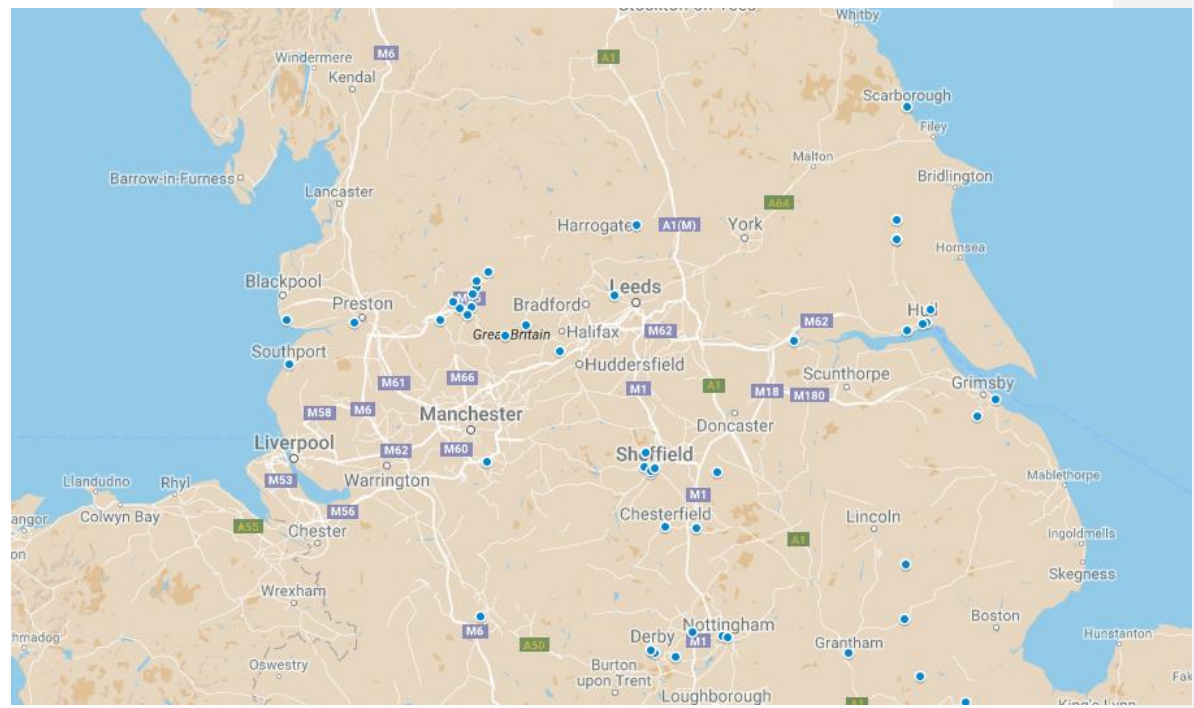

This tentative mapping and the clear non-conformist associations clearly places these events as largely organised by working-class or lower-middle-class women, generally church or chapel-going. This is small town Britain of coal mines, textile mills and fishing industries. These towns may have cinemas, but would often lack theatre, music halls, museums, galleries and higher education institutes. They are also some distance, using transport available to the working class, from cities where these things could be found. At this time, there would have been a considerable difference in opportunities between the Pennine town of Burnley, and the comparatively urban Bury, only a tram ride to buzzing, political Manchester. Cause and effect are blurred here - these areas were neglected by the establishment and thus became non-conformist strongholds, while their continuing poverty of opportunity meant the phrase "making your own entertainment" could have been invented for them. 
As the voices of provincial, working-class women were rarely heard or recorded in this era, it is fascinating to see who they chose as heroines, representatives and role models.

\section{The Pageants: The Chosen Heroines}

Though there is some cross-over with the original "Pageant of Great Women", there are significant differences. Cicely Hamilton's groups were: saintly women, rulers, learned women, artists, heroic women and warriors. Wakeford's groups, which became a model for many performances, were: Champions of Liberty, The Light Bringers, Women of Great Renown, Life Savers, Seers of Vision, Uplifting and Purity and a Mother. Later groups included Bible Characters and Emancipators of Women.

\begin{tabular}{|c|c|c|}
\hline Character & Mentions & \\
\hline Florence Nightingale & 30 & Founder of modern nursing in war, statistician and social reformer \\
\hline Boadicea & 29 & Martial leader against the Romans \\
\hline Grace Darling & 29 & A lighthousekeeper's daughter who rescued victims of a shipwreck \\
\hline Joan of Arc & 29 & Christian visionary, martial leader. \\
\hline Elizabeth Fry & 29 & Quaker, prison reformer \\
\hline Queen Elizabeth & 27 & \\
\hline Queen Victoria & 26 & \\
\hline Queen Bertha & 24 & Queen of Kent, influenced the Christianisation of Anglo-Saxon England \\
\hline Susannah Wesley & 24 & Mother of Methodism \\
\hline Catherine Booth & 24 & Mother of the Salvation Army, campaigned for women preachers \\
\hline Margaret Queen of Scots & 24 & Born an English princess, known for her piety and charity \\
\hline Harriet Beecher Stowe & 23 & Calvinist, writer and anti-slavery campaigner \\
\hline $\begin{array}{l}\text { Elizabeth Barrett } \\
\text { Browning }\end{array}$ & 23 & Poet, wrote against slavery and child labour. \\
\hline Hypatia & 22 & Greek mathematician \\
\hline Sister Dora & 22 & C19th Anglican nun and nurse in Walsall \\
\hline Huguenot woman & 21 & Protestant, many were martyred in religious wars \\
\hline Mme Roland & 21 & Campaigned in favour of the French revolution, guillotined \\
\hline Saint Genevieve & 20 & Crossed enemy lines to bring food during a C5th siege of Paris \\
\hline Josephine Butler & 20 & Visionary and social reformer concerned with the welfare of prostitutes \\
\hline Mother & 20 & \\
\hline Edith Cavell & 20 & Nurse, executed by the Germans in the Great War \\
\hline Clio, muse of history & 19 & \\
\hline child of the time & 17 & \\
\hline
\end{tabular}




\begin{tabular}{|l|r|l|}
\hline Alice of Lisle & 16 & Presbyterian, executed for sheltering anti-Royalist soldiers \\
\hline Mary Slessor & 16 & Presbyterian, missionary to Nigeria who promoted women's rights \\
\hline Frances Havergal & 10 & Anglican religious poet and hymn writer \\
\hline Frances Willard & 9 & Methodist, Temperance reformer and women's suffragist \\
\hline
\end{tabular}

Table 1: Number of times the twenty five most popular characters (plus Clio and Child of the

Time) are mentioned appearing in thirty two pageants for which we have full lists. Full rankings in Appendix 2.

But although it is possible to list who was chosen, it is much more difficult to know why they were chosen, and what was their significance to their audiences. Newspapers carried cast lists, but not interviews with producers and only rarely commentaries. Lacking a complete script, we cannot know how these characters were represented. Was Frances Willard represented primarily as campaigning for Temperance, or Votes for Women? Was Catherine Booth chosen for working with the homeless, or creating a new church? Was Edith Cavell shown only as a nurse and martyr, or was she allowed to speak her famous quote: "Patriotism is not enough"?

We cannot answer these questions, but we can make some speculations based on the choices above.

Of the twenty five most common characters, not including narrator or child, thirteen are married, twelve with children, and eleven are single (Huguenot woman could be either). This positive portrayal of single life may be in contrast to the prevailing opinions of the interwar years, as brilliantly documented by Alison Oram ${ }^{37}$, though they are largely saints and martyrs.

Eight are non-conformists, reflecting the performers as above. Ten could be described as famous for humanitarian works including nursing, prison reform, anti-slavery and missionary work. The remainder include four queens (two famous for Christianity) and two 
saints, St Genevieve and Joan of Arc. There are only two warriors, Boadicea and Joan of Arc. Although several are educated professional women (including Madame Roland, Florence Nightingale, Harriet Beecher Stowe and Edith Cavell) only one, Greek mathematician Hypatia, is famous for purely intellectual work.

Many are known not just for their deeds but for their voices and willingness to give voice to the voiceless. Catherine Booth campaigned vigorously for the right to women to preach to mixed groups in church; Josephine Butler spoke on the taboo topic of prostitution; Elizabeth Fry did the same for prisoners; Elizabeth Barrett Browning and Harriet Beecher Stowe were known as much for their liberal political views as their literary work. We do not know if this is why they were chosen, but we do know that they were not excluded from the list for this behaviour. This willingness to transgress social norms in a worthy cause is a particular feature of the non-conformist tradition, particularly in the Society of Friends. Regarding $19^{\text {th }}$ century missionary Hannah Kilham, Alison Twells said: "Experiencing her calling in her heart, she was empowered by the doctrine of the inner light to transgress the boundaries of both the female province and established Quaker practice." ${ }^{38}$ The same could be said of the group listed above.

It is particularly notable that the role of "Mother" was missing in Cicely Hamilton's production, but was present in twenty out of the thirty-two later productions for which we have listings.

In contrast to Cicely Hamilton's play, the archetypal figure of "A Mother" frequently appears. Scholars have argued about the anti-feminist or otherwise interwar emphasis on motherhood $^{39}$, but I would argue that in this case, it reflects the conditions of performers and audience. For most of them, motherhood was the central fact of their lives, the focus of most of their work and success. In including this character, they validated and honoured 
themselves as playing a valuable, if unsung, part in society. Maggie Andrews' work on the Women's Institutes' campaigns also details how this validation of the importance of mothers could be itself political, empowering women to make demands about housing standards, piped water and electricity for rural areas, and representation on national committees. ${ }^{40}$

It is also worth considering the women who are conspicuously absent, or very low down the list.

Most of Hamilton's warriors have disappeared. Those remaining are Joan of Arc, now listed under "Seers of Vision", Boadicea, now under "Champions of Liberty", and Florence Nightingale, now under “Life Savers". In other words, the category of women defined as great for being warlike has disappeared, and those heroines who have been retained are now praised for other qualities. This echoes research by Julia Neville ${ }^{41}$, who examined Honiton and Ilkeston pageants in her work on Heroes and Leaders, "No More Civil Disobedience?". She suggested the former "militant" role models required by the suffragettes were no longer fit for purpose, and had to be replaced by a new roll call stressing Liberty, Christianity, Humanity, Vision and Motherhood.

Most of Cicely Hamilton's learned women have also disappeared, with the exceptions of Hypatia, French revolutionary Madame Roland and Madame Curie (just missing from the above table with eight mentions). EP Thomson castigated the Methodists' "antiintellectualism", perhaps this is reflected here. ${ }^{42}$

Ada Lovelace does not feature. Other scientists do appear, including sociologist Harriet Martineau (six mentions) and astronomer Mary Somerville (seven), so this may be because the importance of her work was simply unrecognised outside mathematical circles until the advent of modern computing. The German-born astronomer Caroline Herschel is 
missing, although a banner with her name was carried in a suffragette parade and she appeared in Hamilton's pageant: could this be a result of anti-German sentiment?

Again in contrast with Hamilton's choices, there are no artists. The creatives honoured are hymn writers Frances Havergal and Fanny Crosby (who was also a mission worker, eight mentions), poets Anne Bradstreet (six) and Elizabeth Barrett Browning (also famed for her humane views, including verses on the slave trade and British child labour) and novelists Charlotte Bronte and Harriet Beecher Stowe (best known for her anti-slavery campaigning). Performers are also rare: singers Madame Melba and Dame Clara Butt and Shakespearean actress Sarah Siddons make only two appearances each. As with the inclusion of "A Mother", these choices may reflect the performers' lived experiences. Few will have visited art galleries; trips to professional theatres or concerts would be a very rare treat. In contrast, quality novels were readily, cheaply available in Sunday School and public libraries, and hymns would form the soundtrack of their lives. Many chapels were known for their very high standard of choral singing, and the Non-conformist Choir Union Festival was a huge annual event held at Crystal Palace. It still exists as the Free Church Choir Union.

Amongst writers, Mary Shelley is absent, perhaps her Gothic horror was seen as unChristian. More suprisingly, Jane Austen never appears, apparently idle Regency women searching for advantageous marriages did not appeal to this audience. George Sand is also absent, perhaps because of her many romantic and possibly lesbian affairs, though both Austen and Sand featured on Hamilton's list. Charlotte Bronte, who was not honoured by Hamilton, appears five times, but her sisters only twice, and only as "Charlotte Bronte and sisters". Again, Jane Eyre's independence and dauntless morality may be more appealing to this hard-working and largely Christian audience than the passions of Wuthering Heights' landowners. 
Several feminist and suffrage campaigners appear but none makes more than a handful of appearances: Mary Walstonecroft (four mentions), Mrs Pankhurst (three mentions) and Dr Elsie Inglis (two mentions). This may be because so many women were involved that a pre-eminent name had not clearly emerged. The most popular is Frances Willard with nine appearances, but this may be because of her Temperance campaigning. Catriona Beaumont has discussed how many organisations placed an emphasis on citizenship, disassociating themselves from feminism, which may explain this muted recognition for the previous generation of campaigners. ${ }^{43}$

Also missing are non-white and non-Christian women - almost the entire list is British or American, with a handful of European and Biblical characters. In this it is less outward-looking than Cicely Hamilton's production, which included Indian, Chinese, Russian and many European women. The producers could be criticised against present standards for their limited world view, but in a sense their choices show a very contemporary concept, the idea of tailoring content for a demographic, or, in magazine terms "reflecting the reader" ${ }^{44}$.

Considering that these are largely productions by Christian organisations, the Biblical choices are perhaps the most interesting. The following, who are most likely to feature in stained glass windows and to have churches named after them ${ }^{45}$, are entirely absent: the Virgin Mary, Mary Magdalene, the sisters Martha and Mary who listened to Jesus and cooked his dinner, all the Old Testament's famous mothers (Rebecca, Sarah etc), Saint Anne (mother of the Virgin Mary), Saint Elizabeth (mother of John the Baptist), Saint Catherine (a C4th virgin martyr) and Saint Helena (mother of Constantine). Saint Margaret, also a popular church name, features in our list as Queen Margaret of Scotland, which is how these Protestant women knew her. 
Instead, the tableaux organisers appear to have combed their heritage for a completely different pantheon. Their saints are Joan of Arc (twenty nine mentions), Saint Genevieve (twenty mentions, during a blockade of Paris she passed through siege lines to bring grain and negotiated with the conqueror Childeric for prisoners), Saint Cecilia (four mentions, patron saint of music who refused to marry), and Monica (three mentions, mother of Saint Augustine who worked tirelessly to reform him). Old Testament women Naomi and Ruth, often portrayed as a model of female friendship, have six mentions.

Two groups, from a Baptist chapel in Hebden Bridge, Yorkshire, and a Methodist Church in Penzance, both used very similar groupings ${ }^{46}$ including an identical "Bible Characters" section. The list seems an attempt to reclaim the Bible as a source of inspiration and justification for independent women. There are two prophetesses, Miriam and, more controversially, Deborah. She led an Israeli army after the general refused to go to war without her. Ruth and Naomi are included, as is Lydia, a wealthy New Testament trader and Christian convert.

But the most extraordinary inclusion is an argument for sexual freedom through the Woman of Samaria, held up by these non-conformist ladies as a noble woman. Jesus asked the Woman of Samaria to draw him a drink of water, telling her he would give her living water. The story continues: 'Jesus said to her, "Go, call your husband, and come here.” The woman answered him, "I have no husband." Jesus said to her,"You are right in saying, 'I have no husband'; for you have had five husbands, and the one you now have is not your husband. What you have said is true." The woman said to him, "Sir, I perceive that you are a prophet." The woman later told the people of the town that Jesus was the Messiah, saying "Come, see a man who told me all that I ever did. Can this be the Christ?" As a result, many believed in him. (John, 4:29) Unlike the woman caught in adultery (John, 8:1-11), it is not written that Jesus told her she was a sinner, or to change her behaviour, or that she ever did 
so. The chapel stages were known for their robust and sometimes bawdy humour ${ }^{47}$, so this may have been an opportunity for some fun. However, according to the Hebden Bridge pageant notes, the Woman of Samaria was played by Mrs Lingard. No first name or initial is given, suggesting she was a widow. Perhaps the part was too risque to give to an unmarried woman or wife.

Finally, the notes above should not be taken as implying these lists were generic. Although there are staple characters, there was also much room for individual choices. Many tableaux featured local heroines or favourites, in thirty two lists, sixty two choices appeared only once (see Appendix B). Some were controversial - the press clearly enjoyed the outrage over the inclusion of Lady Godiva, whose costume weighed less than one and a half ounces ${ }^{48}$.

To summarise, these lists represent women who are active, tireless workers. They are courageous, both physically and morally. They may be married or single, though if married they are famous for their own works, not their husband's position. Though rulers are heavily represented, only non-conformist martyr Alice of Lisle is noble in the aristocratic sense. They are likely to be well-educated by the standards of their time, but are unlikely to pursue intellectual work for its own sake, and are more likely to use their education in the service of others, or for campaigning for the unfortunate. They are likely to be strong-minded, opinionated and out-spoken, often against the prevailing social norms, though only in the service of morality, Christianity and the rights of women and the unfortunate. They are unlikely to be explicitly feminist (though they may be feminist in all their actions) and are highly unlikely to be overtly sexual or known for their beauty. Women who break social norms for self-centered ends, such as personal gain, fame or sexual satisfaction, are excluded. In demographic terms, they reflect the performers in being largely white, English-speaking and with a bias towards Christianity and non-conformism. 


\section{The Pageants: newspaper reports}

In view of the fact that the mainstream media, particularly women's magazines, has been accused of peddling a very conservative view of femininity during this period ${ }^{49}$, it is worth briefly considering the local newspapers' reports. With a single exception ${ }^{50}$, they were overwhelmingly positive. There is an economic case here - local newspapers are far more reliant on maintaining a good relationship with a community than a national newspaper or magazine is. A scathing report of an amateur production could mean dozens of cancelled subscriptions and a dent in profits. However, these reports sometimes do more than pay lip service. They include quotes such as this from the Western Gazette on $20^{\text {th }}$ December, 1935 :

The imagination of the audience was deeply stirred, and all left with the sense that they were debtors to a noble line of heroic and saintly women, without whom the freedom, and grace, and sweetness of the present could never have been.

A slightly different pageant, which showed scenes of women's emancipation, such as

Lord Shaftesbury's inquiry and the gain of legal rights for married women, was described by

the Sunderland Daily Echo and Shipping Gazette, on $26^{\text {th }}$ May 1938:

The pageant was aimed to show the vast change which has come over the conditions of woman's life in the past century, and the possibilities which the future holds - 'woman triumphant is woman helping in the creation of a happy world.'

The Cornishman, on $25^{\text {th }}$ April 1940, said a more appropriate theme for a pageant

could hardly have been chosen than the lives of noble women:

The pages of history had been turned over, and the influence that women have exerted in the regeneration of mankind and the improvement in the social conditions were recalled in a way that will make them unforgettable to all those present. It is well that this should be so, as in these days of strife and warfare, the part that women have played is liable to be over-looked. 
These enthusiastic tributes both to the performers and the concept of the pageants suggest that mainstream thought was not necessarily against this type of revisionist history, or against the public veneration of powerful women as role models for the next generation.

\section{Why the non-conformists?}

The heavy non-conformist involvement in these events, far beyond that of any CofE or secular organisations, is one of the most striking results. As stated above, it is difficult to separate cause from effect here, as the small towns and isolated regions that were attractive to wandering dissenting preachers in the $17^{\text {th }}$ and $18^{\text {th }}$ centuries may also be the areas that continued to nourish radical views, whilst also lacking professional entertainments or higher education institutes. As Michael Woods has said, the original concept of the historical pageant from 1905 was intended for small towns, and, although many large cities embraced the concept, by 1928 the high tide of "pageanitis" had ebbed and they were again most popular in smaller towns ${ }^{51}$. However, there are reasons to think the non-conformist churches may have been particularly receptive to the production of a feminist revisionist history.

Firstly, the movement itself was originally based partly on the belief that women could preach. An unbroken, if wavering, line of women preachers can be traced through the movement. Quakers and other dissenters were famous for their acceptance of women preachers from the early days ${ }^{52}$, which is one of the reasons they were persecuted, as Boose demonstrated in her work on the use of the scold's bridle for publicly-preaching female dissenters $^{53}$. John Wesley also supported some women preachers, and although the practice all but died out in mainstream Methodism after his death, it continued in many other branches such as the Primitive and Independent Methodists, Congregationalists etc, and returned to Connexion churches in the $1860 \mathrm{~s}^{54}$. Valenze traced more than 200 female preachers between 
1790 and 1850 preaching in the radical evangelical "cottage" churches in the South West, Midlands and North of England ${ }^{55}$, the same areas mapped above.

But although the history of dissenting churches in the $19^{\text {th }}$ Century is one of fractures and splits, it may be a mistake to make too much of these divisions. Members, preachers and entire congregations could move between chapels, as preacher Hannah Kilham moved from Wesleyan Methodism to the New Connexion and then the Quakers ${ }^{56}$; or even start their own, as did Catherine Booth, who, after campaigning for women preachers with her Methodist minister husband, left to start the Salvation Army. Women were also granted some power within the church, though this varied. For example, the Yorkshire Baptist Association decided in 1719 that women could vote in church meetings - unless they outnumbered men. ${ }^{57}$ Women were allowed to become deacons in the mainstream Methodist churches from 1890, and could be ordained from 1974 (compared to 1985 and 1992 in the Church of England in England). This more progressive view is pointed up in their response to a Government survey, when the Free Churches supported the use of contraception which the CofE and RC churches opposed ${ }^{58}$. Taken together, it is reasonable to say that nonconformist chapels held a generally progressive, if uneven, attitude to women's rights compared to the Church of England or RC churches.

Secondly, the non-conformist churches always had political functions. Their formation was a political act, and they maintained close links with Chartist and trade union movements, whilst teaching literacy in the Sunday School movement. ${ }^{59}$ Halevy credited Methodism with playing a role in preventing revolution in Britain, with EP Thomson taking a negative slant on the same issue with accusations of anti-intellectualism ${ }^{60}$, but the Halevy thesis of a central and conservative role for Methodism has been challenged by Valenze's and Walker's work, above, which acknowledges the many smaller churches and organisations with more radical views ${ }^{61}$. Liddington and Norris ${ }^{62}$ also briefly acknowledge the chapel 
influence in their work on the women's suffrage movement, particularly when writing of the formation of the Independent Labour Party in the 1890s: "In the Lancashire cotton towns and the West Riding wool villages on either side of the Pennines the traditions of Nonconformism and temperance were particularly strong, and gave their ILP branches an atmosphere of self-disciplined 'high thinking and low living'." These are the towns which feature as a distinctive cluster between Preston and Bradford on Figure 2.

Thirdly, the non-conformist churches were strongholds of educational and other secular functions, which may have been more significant than their sacred functions. There is much primary evidence of the breadth of functions chapels provided, though little is electronically searchable. Centenary booklets held by local libraries are informative. For example, material held at West Yorkshire Archive on the now closed Midgley Methodist Church, in a tiny hillside village near Halifax, show that through the $19^{\text {th }}$ Century it had not only a Sunday School with 42 teachers and 269 scholars, but also children's, youth and adult groups, and regular concerts and social functions. One Easter event included a dialogue on "Woman's Rights" (“no woman should miss it”) and a men's washing competition. Built by local communities as a public good, the Sunday Schools could be larger and grander than the chapels themselves, with extensive libraries.

Lastly, the chapels and their Sunday Schools were a female-dominated space, often the only communal space in a small town except for the pub, and far more suitable for respectable working-class women. Maggie Andrews has discussed the importance of a female space in her work on the Women's Institute, and the chapels fulfilled a similar function, with groups such as all-female drama groups not uncommon.

However, academic research is thin. The rarity of references may partly result from London-centric views and the remnants of the Victorian establishment's disparagement of the 
vigorous new provincial movement whose chapels were, according to Britain's only religious census in 1851 , better attended than the Church of England ${ }^{63}$, but it is likely to be partly because research is exceptionally difficult due to the lack of central organisation and archives for most chapels, which were often self-governing. Many hundreds closed without fanfare from the 1950s onwards, with their rich social histories reduced to a few souvenirs kept by elderly former members and thrown away as rubbish on their deaths. Susan Mumm has described this "survival bias" in history in her work on philanthropic organisations, explaining that smaller, local organisations may do a huge amount of work but are less likely to leave a record trace or to be subject to later interest ${ }^{64}$. An equivalent to Catriona Beaumont's research on Women's Institutes, Townswomen's Guilds, the YWCA and other national organisations would be an enormous project. Her own book, "Housewives and Citizens" contains only one brief reference to the Free Church Women's Council and none to Methodists, Baptists, or any of their many Sisterhoods, Dorcas Societies etc. The very fragmentary and informal nature of provision such as lecture programmes in individual chapels militates against it being subject to the kind of examination that June Purvis gives to the Mechanics' Institutes and Women's Co-operative Guild ${ }^{65}$.

As stated above, the lack of other organisations in these small towns may be the reason why they played host to these events, but the crossover with areas where nonconformist culture was strong is still of interest. There is a case for considering that the nonconformist culture itself, with its long tradition of political activism and women's public speaking, provided a fertile ground for expressions of feminist history.

\section{Joining the Establishment}


The non-conformists may, as their name suggests, be outside the establishment, but the characters chosen may have been part of a more general movement towards it. By the 1930s theirs was no longer a firebrand movement. Like the women's suffrage movement, many of their once-radical ideas had been absorbed into the mainstream. These pageants may have reflected a desire, both by non-conformists and women's campaigners, to join the establishment.

Without a British script, or body of scripts, it is impossible to say with certainty what the purpose of these productions were, and whether they were overtly focussed on social or political change. However, the choices of characters, with an emphasis on traditional Christian values and the almost universal inclusion of monarchs, suggests these were not radical productions. The Australian script certainly has a traditionalist, patriotic tone, with one character playing "Pioneer Woman". The final scene ends with Queen Victoria singing "Land of Hope and Glory", followed by the narrator calling on women present to make the British Empire mightier yet. The Spirit of Womanhood recites Kipling's Recessional and all join in singing Kipling's "Land of Our Birth".

We do not know if this overt nationalism was also common in the British pageants, but it seems possible given the characters chosen. This patriotic sentiment may seem at odds with the common feminist narrative of radicalism. Alison Light, mentioned above, has described how much feminist history has ignored the small-c conservative, but popular culture at the time, as she points out, was full of expressions of small-c conservatism. This expression of patriotism and even nationalism was certainly common at the time in other pageants, such as Taunton ${ }^{66}$, and in other cultural expressions such as the singing of God Save the King at the end of every theatre cinema performance. By including this within women's pageants, the performers may have sought to include their pageants as a normal expression of British culture, which is in line with their redefining of history as a continuum 
of great women, of which their present generation of enfranchised women is an extension, not an oddity or revolution. Similarly, as non-conformists they may have sought to have their heroines such as Catherine Booth and Elizabeth Fry grouped with Florence Nightingale and Grace Darling.

Michael Woods has discussed the various uses of public drama in the form of pageants, which include demonstrating an elite's power through the occupation of symbolically significant space and promoting discourses which legitimise the elite's leadership. In this case, we are not considering an elite, but rather a new group which seeks to join the elite by demonstrating their historical right to do so. He also points out that historically public drama was used to confirm the social and political order, especially during and after times of turbulence. ${ }^{67}$ These points seem particularly relevant in the case of the interwar pageants. They were performed, often in a chapel or public hall, sometimes in huge public spaces such as Victoria Hall, Sheffield. They also confirm a social and political order following turbulence, in this case, a new order. The pageant may serve to reassure the participants and spectators that in fact the order has not significantly changed but is part of a continuum of strong and successful women, and socially valuable non-conformists, stretching back into Britain's past.

Laura Mayhall has also pointed out that the militant WSPU enshrined a narrative of authentic suffrage militancy in the 1930s which has dominated discussions of the movement and subsequent feminist ideology ever since ${ }^{68}$, to the diminution of the "constitutional wing", but the debate about what constitutes feminism is widening. Recently, Catriona Beaumont and Maggie Andrews' histories of “housewives' associations” including the WI and Mothers' Union which encouraged their members to take part in politics, ran successful campaigns on national issues and started businesses whilst remaining rooted in domesticity and without 
challenging gender roles. This group of pageants could certainly fit within this new narrative of "moderate feminism" or empowerment.

\section{Conclusion and Further Research}

If nothing else, I hope this paper will be a starting point for bringing back into public knowledge many women who were clearly heroines of their time, and whose names have since been lost. Many would doubtless justify entire biographies of their own. The full listing in Appendix 2 throws up many mysteries, particularly in the one and two mention categories. However, the very fact that so many of these names are unknown to the casual reader suggests that the pageant organisers did not totally succeed in promoting their heroines as nationally important figures. The revised history they sought to create has not, after all, become mainstream, although the concept of the importance of celebrating women's achievements and history has become more widely acknowledged, as the success of this journal demonstrates.

This paper outlines the choices that the producers of these pageants have made, and provides some suggestions as to why they have made them. It does not exhaustively analyse each of these choices beyond placing them within broad groups. It would be interesting to examine some of these choices further. Julia Neville has used Google Books to track how mention of such characters as Edith Cavell disappeared over time. Tracking the rise and fall of the fame of these and other women could open up many further avenues of discussion about why and how we choose our role models. It may also be interesting to consider how we choose role models today. The many women's magazine awards programmes could be a field of study, but it is hard to think of a direct parallel of modern celebrations of heroines of the past. When did we stop venerating our ancestors' achievements? 
This research also highlights the richness of the local press archives, now becoming available through the digitisation programme. These newspapers, being closer to the communities they served, may provide a more accurate picture of the grassroots social history of Britain than the national press, which has previously tended to be the focus of academic study. The British Press Archive allows the searching and examination of local records from all over Britain side-by-side in a way that has not been possible before.

Beyond this, the whole area of life in non-conformist chapels, particularly for women, is well worthy of study. Major social and religious movements such as the British Baptists, Female Revivalists, Primitive Methodists and Congregationalists are being reduced to a footnote in history, if that. It has been noted previously, through the many references given above, that there was a natural resonance and affiliation between religious non-conformity and social and political non-conformity or even radicalism, although this waxed and waned. However, this has been barely explored in relation to women's issues. Although this research helps make the link explicit through the groups that chose to perform these pageants, many other avenues of research are possible.

These women, though provincial and working or lower middle class, were far from passive observers of changing times. They were taking an active interest in the world around them and were creating a new history and inspiration for themselves and the next generation. The heroines they chose clearly indicate how they consider greatness and nobility to be defined --- through intelligence, hard work, service to others, a willingness to speak out and the courage to break with social norms for higher causes. 


\section{Supplemental Data}

Supplemental data for this article can be accessed at the University of Central Lancashire clok site. (link will be inserted when it has been uploaded)

\footnotetext{
${ }^{1}$ Now held in the West Yorkshire Archive at Halifax Library.

${ }^{2}$ The British Newspaper Archive is a digitisation project by the British Library, available at http://www.britishnewspaperarchive.co.uk.
}

${ }^{3}$ The script by Cicely Mary Hamilton, published in 1910 by the Suffrage Shop, was digitised by Google from the University of Michigan's copy and is available at https://archive.org/details/apageantgreatwo00hamigoog. Also see, Katharine Cockin (2005) Cicely Hamilton's warriors: dramatic reinventions of militancy in the British women's suffrage movement. Women's History Review 14:3-4 pp. 527-542.

${ }^{4}$ Michael Woods (1999) Performing Power: local politics and the Taunton pageant of 1928, Journal of Historical Geography 25:1, pp 57-74

${ }^{5}$ Paul Gardullo (2013). Spectacles of Slavery: Pageantry, Film and Early 20th Century Public Memory. Slavery and Abolition: A Journal of Slave and Post-Slave Studies 34: 2 pp.222-235.

Juanita Karpf (2011) Get the Pageant Habit: E Azalea Hackley's Festival and Pageants in the First World War Years. Popular Music and Society 34:5 pp.517-556.

Just a few contemporary examples of pageant planning include: Martha Willard (1925) History Project - A Semi-Pageant. Historical Outlook 16: 6 pp.278-281.

Elizabeth Anderson (1940) Miss Liberty, A folk dance pageant. The Journal of Health and Physical Education, 10:11 pp. 596-639.

Caroline Hotchkiss (1919) A Pageant of the Earth Journal of Geography, 5: 18, pp. 171-178.

${ }^{6}$ Lisa Tickner (1988) The Spectacle of Women: Imagery of the Suffrage Campaign 1907-1914. (First. Chicago: University of Chicago Press)

${ }^{7}$ Margaret E Shepherd (2003) From Hellgill to Bridge End: Aspects of Economic and Social Change in the Upper Eden Valley 1840 to 1895. (University of Hertfordshire Press). Footage of a Manchester Band of Hope Procession by Mitchell and Kenyon, 1901, is available at http://www.filmarchivesonline.eu/viewDetailForm?FilmworkID=3cf9cd2b29cede687344ff62ccdc9aac

${ }^{8}$ Kelly, Katherine (2004) Seeing through Spectacles: The Woman Suffrage Movement and London Newspapers, 1906-1913 European Journal of Women's Studies 11:3, pp327-353

${ }^{9}$ Woman and the Suffrage. The Times. 15 June 1908, p. 9.

${ }^{10}$ Women and the Suffrage. The Times. 12 June 1908, p. 12.

${ }^{11}$ Crawford, Elizabeth (2014) Suffrage Stories: An army of banners designed for the NUWSS Suffrage Procession 13 June 1908. . http://womanandhersphere.com/2014/11/26/suffrage-stories-an-army-of- 
banners-designed-for-the-nuwss-suffrage-procession-13-june-1908/ (accessed July 2, 2015). There was a long tradition of women making political banners, mentioned by EP Thompson (1963) The Making of the English Working Class (IICA: England). Establishment figures were lamenting the fact that the "pious sisterhood" were embroidering radical banners for the Chartists in Newcastle in 1818.

12 10,000 women march for suffrage. The Observer. 14 June 1908.

${ }^{13}$ Diane Atkinson, Anna Sparham, and Margaret Denny (2015) Soldiers and Suffragettes: the Photography of Christine Broom. (London: I B Tauris)

${ }^{14}$ Cockin. Cicely Hamilton's warriors: dramatic reinventions of militancy in the British women's suffrage movement.

${ }^{15}$ Rebecca Cameron (2009) From Great Women to Top Girls: Pageants of Sisterhood in British Feminist Theater. Comparative Drama 43:2 pp 143-166.

${ }^{16}$ Jill Liddington and Jill Norris (2000) One hand tied behind us. 3rd. (London: Rivers Oram Press)

17 Tickner. The Spectacle of Women: Imagery of the Suffrage Campaign 1907-1914.

${ }^{18}$ Ann Marie Nicolosi (2007) The Most Beautiful Suffragette: Inez Milholland and the Political Currency of Beauty. Journal of the Gilded Age and Progressive Era, 6:3 pp.287-310.

Sarah J Moore (2004) Making a Spectacle of Suffrage: The National Woman Suffrage Pageant, 1913. Journal of American Culture 20: 1 pp.89-103.

Jennifer L Borda (2009) The woman suffrage parades of 1910-1913: Possibilities and limitations of an early feminist rhetorical strategy. Western Journal of Communication 66:1 pp.25-52.

${ }^{19}$ Harriot Stanton Blatch. Why Suffragists Will Parade on Saturday. New York Tribune, 3 May 1912 pp 1.

${ }^{20}$ See, for examples, Red Media Pack. 2014a.

http://hearstcouk.wp.cdnds.net/tmp/wpro1410508012414047/2014/07/RedMedia_Aug_14.pdf

(accessed July 10, 2015), and Cosmopolitan Media Pack. 2014b.

http://hearstcouk.wp.cdnds.net/tmp/wpro1410507987703195/2014/07/CosmoMediaPack_2014_v4Au gust2014.pdf (accessed July 10, 2015).

${ }^{21}$ Angela K Smith (2003) The Pankhursts and the war: Suffrage Magazines and the First World War propaganda, Women's History Review, 12:1, 103-118.

${ }^{22}$ Relevant articles included

Julie V Gottlieb (2014) Introduction: 'flour power' and feminism between the waves, Women's

History Review, 23:3, pp.325-329.

Esther Breitenbach and Valerie Wright (2014) Women as Active Citizens: Glasgow and Edinburgh c1918-1939, Women's History Review, 23:3, pp.401-420

Maria DiCenzo (2014) Our Freedom and Its Results: measuring progress in the aftermath of suffrage,

Women's History Review, 23:3, pp.421-440

${ }^{23}$ Adrian Bingham (2004) An Era of Domesticity? Histories of Women and Gender in Interwar Britain, Cultural and Social History, 1:2, pp.225-233. 
${ }^{24}$ Jacqueline R deVries (1998) Challenging Traditions: Denominational Feminism in Britain 19101920. In borderlines: Gender and Identities in War and Peace, 1870-1930, Ed. Billie Melman (London: Routledge)

${ }^{25}$ Light, Alison (1991) Forever England: Femininity, literature and conservatism between the wars. (London: Routledge)

${ }^{26}$ Holley, Rose (April 2009). "How Good Can It Get? Analysing and Improving OCR Accuracy in Large Scale Historic Newspaper Digitisation Programs". D-Lib Magazine. Retrieved 5 January 2014

${ }^{27}$ Marjorie Latta Barstow Greenbie (1917) A Pageant of Noble Ladies. (New York: RC Penfield)

${ }^{28}$ Masque of Noble Women Western Gazette. 20 December 1935 pp.9.

${ }^{29}$ Lancashire Evening Post. 29 March 1934.

${ }^{30}$ The programme, including cast list, and part of the script, is held at the Bristol Record Office, ref 38017, documents relating to the work of Miss Norma Macdonald-Stewart.

${ }^{31}$ Vivienne Richmond (2007), "It Is Not a Society for Human Beings but for Virgins": The Girls' Friendly Society Membership Eligibility Dispute 1875-1936‥ Journal of Historical Sociology, 20: 304-327. doi:10.1111/j.1467-6443.2007.00314.x

Also Susan Mumm (2010), Women and Philanthropic Cultures, in Women, Gender and Religious Cultures in Britain, 1800-1940, Eds Sue Morgan and Jacqueline deVries (London: Routledge).

${ }^{32}$ Pageant of Essex Women. Chelmsford Chronicle. 15 May 1925 pp.5.

${ }^{33}$ Pageant of Noble Womanhood, Novel Entertainment at Penzance. The Cornishman. 25 April 1940 pp.6.

${ }^{34}$ In case any reader should suspect prejudice, the author would like to point out she is contentedly Church of England.

${ }^{35}$ 1,000 Guild Members to Take Part in Pageant, Sunderland Daily Echo and Shipping Gazette, 3 May 1938.

${ }^{36}$ Hugh McLeod (1986) Religion. In Atlas of Industrialising Britain, by J Langton and RJ Morris, 212-217.( London: Methuen Hume)

${ }^{37}$ Alison Oram (1992) Repressed and thwarted, or bearer of the new world? The spinster in inter-war feminist discourses. Women's History Review, 1:3, pp.413-433.

${ }^{38}$ Alison Twells (1998) Let us begin well at home: class, ethnicity and Christian motherhood in the writing of Hannah Kilham 1774-1832 in Radical Femininity: Women's self-representation in the public sphere, Ed. Eileen Janes Yeo (1998) Manchester University Press: Manchester.

${ }^{39}$ See DeVries, footnote 22 
${ }^{40}$ Maggie Andrews (2015) The Acceptable Face of Feminism: The Women's Institute as a Social Movement (Lawrence \& Wishart: London)

${ }^{41}$ Though her work in this field is largely unpublished, Dr Julia Neville has made some notes available at https://heroesandleaders.wordpress.com/

${ }^{42}$ EP Thomson (1963) Making of the English Working Class (London: Victor Gollancz Ltd), see endnote 51 for more details.

${ }^{43}$ Catriona Beaumont (2000) Citizens not feminists: the boundary negotiated between citzenship and feminism by mainstream women's organisations in England, 1928-1939. Women's History Review, 9:2, pp.411-429. Also, Catriona Beaumont (2013) Housewives and Citizens. (Manchester University Press)

${ }^{44}$ Jenny McKay (2013) The Magazines Handbook. (Routledge)

${ }^{45}$ According to Miss Arnold Forster's monumental three volume work (1899) 'Studies in English Church Dedications.' New church dedications are fairly rare, so her work is still valid. Available at: https://stchrysostoms.files.wordpress.com/2011/03/studies-in-church-1.pdf

${ }^{46}$ Grace Cockcroft, see endnote 1, and The Cornishman, see endnote 31. The framings are different though the characters are nearly identical. Presumably a number of scripts were then in circulation and were constantly "cut and pasted" and otherwise re-adapted.

${ }^{47}$ Amy Binns (2013) Valley of a Hundred Chapels. (Grace Judson Press)

${ }^{48}$ Cheers for a Lady Godiva after Bramley Pageant Dispute. Hartlepool Northern Daily Mail, 29 July 1935 pp.4. Also, Bramley Pageant Protest. Yorkshire Post and Leeds Intelligencer, 25 July 1935 pp.4.

49 Jill Greenfield and Chris Reis (1998) Women's magazines and the commercial orchestration of femininity in the 1930s: Evidence from Woman's Own.” Media History 4: 2 pp.161-174.

${ }^{50}$ LH Reilly (1929) Our Ladies' Column: Achievement, Bucks Herald 21 June, pp 15. This pageant was part of a wider event including a handicrafts exhibition. Ms Reilly has struggled to combine a sermon on the importance of reviving lacemaking compared to becoming "MPs, KCs and what not" with a polite report on the Pageant of Famous Women.

${ }^{51}$ Michael Woods, ibid.

${ }^{52}$ Boswell's Life of Johnson recorded: 'Sir, I told him I had been that morning at a meeting of the people called Quakers, where I had heard a woman preach. Johnson: 'Sir, a woman's preaching is like a dog's walking on his hind legs. It is not done well; but you are surprised to find it done at all.'

${ }^{53}$ Boose, L. E., 1991. Scolding Brides and Bridling Scolds: Taming the Woman's Unruly Member. Shakespeare Quarterly, 42(2), p. 179-213.

${ }^{54}$ Olive Anderson (1969) Women Preachers in Mid-Victorian Britain: Some Reflexions on Feminism, Popular Religion and Social Change. The Historical Journal, 12, pp467-484.

Pamela Walker (2010) 'With fear and trembling': women, preaching and spiritual authority in Women, Gender and Religious Cultures in Britain, 1800-1940, Eds Sue Morgan and Jacqueline deVries (London: Routledge). 


\footnotetext{
${ }^{55}$ Valenze, Deborah (1985) Prophetic Sons and Daughters: Female Preaching and Popular Religion in Industrial England (Princeton University Press).

${ }^{56}$ Alison Twells (1998) Let us begin well at home: class, ethnicity and Christian motherhood in the writing of Hannah Kilham, in Radical Feminity: Women's self-representation in the public sphere, Ed. Eileen Janes Yeo (Manchester University Press)

${ }^{57}$ Baldwin, FJ, (1970) The Beginnings of Association Life in Yorkshire and Lancashire. The Baptist Quarterly 23:5, pp 208-214
}

${ }^{58}$ Sue Morgan (2010) 'The Word made flesh': women, religion and sexual cultures, in Women, Gender and Religious Cultures in Britain, 1800-1940, Eds Sue Morgan and Jacqueline deVries (London: Routledge).

${ }^{59}$ Hargreaves, John A (2010) Hat's Off: Methodism and Popular Protest in the West Riding of Yorkshire in the Chartist Era. Wesley Historical Society Proceedings 57:5.

${ }^{60}$ Halevy, Elie, (1949) England in 1815: A History of the English People in the Nineteenth Century London.

E.P. Thompson, in "The Making of the English Working Class", was dismissive of the Methodist contribution to literacy, castigating the Wesleyan "anti-intellectualism", describing their services as "psychic masturbation" and their Sunday schools as inculcating "barbaric and evil superstitions". However, he acknowledged the positive impact in rural areas in terms of increased political and class awareness.

${ }^{61}$ Urdank, Albion (1987) Review of Prophetic Sons and Daughters: Female Preaching and Popular Religion in Industrial England by Deborah M Valenze, The Journal of Interdisciplinary History 18:2, pp 359-361.

${ }^{62}$ Liddington and Norris, see endnote 14.

${ }^{63}$ Ken Powell (1980) The Fall of Zion. Save Britain's Heritage.

${ }^{64}$ Susan Mumm, ibid

${ }^{65}$ See Beaumont, endnote 42. Also June Purvis (1980) Working Class Women and Adult Education in Nineteenth Century Britain. History of Education, 9:3, pp.193-212

${ }^{66}$ Michael Woods, ibid

${ }^{67}$ Tresidder, GA, (1992) Coronation Day celebrations in English towns 1685-1821: elite hegemony and local relations on a ceremonial occasion, British Journal of Eighteenth Century Studies 15, pp132, in Michael Woods, ibid.

${ }^{68}$ Mayhall, Laura E Nym (1995) Creating the suffragette spirit: British feminism and historical imagination, Women's History Review, 4:3, pp319-344.

\section{Appendix 1}

\section{Birchcliffe Baptists' Pageant of Noble Women}


The full listing of the production at Birchcliffe Baptist Church, Hebden Bridge, (see Endnote 1 ) is given here as an example of how characters could be grouped. I have provided annotations in brackets for characters not mentioned above. The production was introduced by the "Spirit of the Ages" and "Dreamer".

Group 1: Bible Characters

Miriam (Aaron's sister, a prophetess)

Deborah

Ruth and Naomi

A Woman of Samaria

Lydia

Group 2: Champions of Freedom and Liberty

Boadicea and her daughters

Margaret Wilson (a Presbyterian Scottish martyr)

Madame Roland

Lady Jane Grey

Dr Elsie Inglis

Harriet Beecher Stowe

Group 3: Pioneers of Christianity and spreaders of Life and Truth

Bertha Queen of Kent

Genevieve

Susannah Wesley

Catherine Booth

Monica

Mary Slessor

Group 4: Emancipators of Women

Hypatia

St Cecilia

Charlotte Bronte and sisters

Mary Somerville (science writer)

Harriet Martineau (sociologist and politician)

Group 5: Women of Great Renown

Queen Elizabeth

Joan of Arc

Frances R Havergal

Elizabeth Browning

Helen Keller

Frances Willard

Nurse Cavell

FD Hemens (successful poet, known for foregrounding the woman's voice)

Fanny Crosby

Group 6: Savers of Life and Sisters of Humanity

Queen Philippa

Grace Darling

Alice, Countess of Lisle 


\section{Sister Dora}

Florence Nightingale

Sister Anne (nurse)

Agnes Weston (philanthropist, superintendent of the Royal Naval Temperance Society)

Group 7: Famed for Love and Purity

Queen Margaret of Scotland

Josephine Butler

Elizabeth Fry

Queen Victoria

\section{Grand Ensemble}

\section{A Mother}

\section{Appendix 2}

Full listing of characters in order of number of mentions in the 32 productions for which we have full details.

Florence Nightingale
Boadicea
Grace Darling
Joan of Arc
Elizabeth Fry
Queen Elizabeth
Queen Victoria
Queen Bertha
Susannah Wesley
Catherine Booth
Margaret Queen of Scots
Harriet Beecher Stowe
Elizabeth Barrett Browning
Hypatia
Sister Dora
Huguenot woman
Mme Roland
Saint Genevieve
Josephine Butler
Mother
Edith Cavell
Clio
child of the time
Alice of Lisle

30 Mary Slessor 16

29 Frances Havergal 10

29 Frances Willard 9

29 Mme Curie 8

29 Fanny Crosby 8

27 Lena Woman of Athens 7

26 Mary Somerville 7

24 Sister Annie of Blackfriars 7

24 Anne Bradstreet 6

24 Naomi and Ruth 6

24 Harriett Martineau $\quad 6$

23 Agnes Weston 6

23 Charlotte Bronte 5

22 Mary Walstonecroft 4

22 Helen Keller 4

21 St Cecilia 4

21 Queen Mary of Scots 3

20 Mrs Pankhurst 3

20 Mrs Beeton 3

20 Monica 3

20 Queen Philippa of Hainault 3

19 Deborah 3

$\begin{array}{lll}19 & \text { Deborah } & 3 \\ 17 & \text { St Hilda } & 3\end{array}$

16 Cleopatra 3

Two mentions:

Dame Clara Butt 


\begin{tabular}{ll}
\hline Mme Melba & Lydia \\
Dr Sharlieb & Woman of Samaria \\
Flora Macdonald & Lady Jane Grey \\
Kitty Wilkinson & Margaret Wilson \\
Queen Bartley & Helen of Troy \\
Sarah Siddons & Dr Elsie Inglis
\end{tabular}

One mention

$\begin{array}{lll}\text { Nameless } & \text { founder of WI Mrs Watt } & \text { Helan of Colchester } \\ \text { Anne Waring } & \text { Egyptian } & \text { Adeliza, Abbess of Barking } \\ \text { sister of the time } & \text { Indian widow } & \text { Elizabeth de Montford } \\ \text { Athlete } & \text { Woman of China } & \text { daughters of Sir Anthony Cook } \\ \text { BWTA } & \text { Katherine Douglas } & \text { Margery Austen } \\ \text { A puritan maid } & \text { Mrs Starr } & \text { Mary Martin } \\ \text { Elizabeth of Hungary } & \text { Lady Godiva } & \text { Judith Freeborne } \\ \text { Mrs Robert Moffat } & \text { Madame Le Brun } & \text { Jane and Anne Taylor of Ongar } \\ \text { Saint or Sister Kirkland } & \text { Britannia } & \text { Amy Johnson } \\ \text { Dorcas } & \text { Puck } & \text { Commandant Allen } \\ \text { Queen Eleanor of Castile } & \text { Queen Philippa } & \text { Madame Pavlova } \\ \text { Bessie of Curfew fame } & \text { Beatrice and Dante } & \text { St Elizabeth of Hungary } \\ \text { Kate Burless } & \text { Atlanta } & \text { St Zita } \\ \text { Emily and Ann Bronte } & \text { Pocahontas } & \text { Margaret Godolphin } \\ \text { Malagasy Martyr } & \text { St Catherine of Sienna } & \text { Christina Rossetti } \\ \text { Barbara Freitchi } & \text { Catherine Gladstone } & \text { Lady Nairne } \\ \text { VAD } & \text { Lady Baden Powell } & \text { Ellen Terry } \\ \text { Christabel and Sylvia Pankhurst } & \text { Mother Shipton } & \text { Amy Johnson } \\ \text { Anahareo wife of Grey Owl } & \text { Jenny Lind } & \text { Munitions and Civil Defence } \\ \text { Fanny Blankers-Koen } & \text { Miss Buss } & \text { FD Hemens } \\ \text { Miss Magnall (Mangnall?) } & \text { Anderson } & \text { The housewife of 1944 with her } \\ & & \text { mop and dustpan } \\ \end{array}$

